\title{
Nutritional recommendations for $n-3$ polyunsaturated fatty acids and the challenge to the food industry
}

\author{
BY S. M. BARLOW, F. V. K. YOUNG AND I. F. DUTHIE \\ International Association of Fish Meal Manufacturers, Hoval House, Orchard Parade, Mutton \\ Lane, Potters Bar, Herts EN6 $3 A R$
}

There are no internationally recognized nutritional recommendations for $n-3$ long-chain polyunsaturated fatty acids (PUFA) simply because the evidence pointing to nutritional requirement in man is mainly only recently derived. The purpose of the present paper is to summarize that evidence and to consider the opportunities and difficulties of incorporating $n-3$ long-chain PUFA in foods.

The present paper will only give a brief account of the history of this subject and will concentrate particularly on the outcome of two major international conferences which took place in the latter half of 1988, to which the world's leading experts were invited. The first was organized by the North Atlantic Treaty Organization (NATO) as an advanced research workshop held in Italy in June 1988 (Galli \& Simopoulos, 1989), and the second was organized by Acta Medica Scandinavica, restricting the invitation to fifty leading medical workers active in this area, which took place in Norway in August 1988 (Nordoy \& Dyerberg, 1990). We will try to present an overall picture of the messages coming from these conferences.

\section{HISTORY}

The expeditions undertaken by Danish physicians (Dyerberg, 1986) to study the living habits of the Greenland Eskimo are regarded as being of major significance in our understanding of the health properties of refined fish oil. However, for many years before these studies of the Greenland Eskimo, fish liver oils were widely recognized as having a positive nutritional role, particularly in the treatment of deficiencies of vitamins $A$ and $D$.

The expeditions to study the Greenland Eskimo focused attention on the possible influence of diet on a major disease facing people in affluent Western society, namely coronary heart disease. The question was asked: 'Why do Eskimos, in spite of their diet containing high levels of fat and protein, experience such a low morbidity and mortality from heart attacks?' (Table 1). The answer according to the Danish physicians appeared to be in the nature of the fat which the Greenland Eskimo was consuming (Table 2). Particular interest was shown in the marine fat present in the Eskimo diet at high levels.

Other observations and comparisons made elsewhere in the world reinforced the view that fish has a dietary role to play in alleviating the effects of coronary heart disease (Dyerberg, 1982; Lands, 1982; Stansby, 1982). These indications led a number of scientists, particularly in the USA to conduct animal experiments to explore which factors in a marine food-based diet were responsible for the apparently beneficial effects pertaining to heart disease and their mode of action. The main factors within the fish oil were found to be two particular long-chain PUFA called eicosapentaenoic acid (EPA; $\left.\mathrm{C}_{20: 5 n-3}\right)$ and docosahexaenoic acid (DHA; $\mathrm{C}_{22: 6 n-3}$ ). These fatty acids were found to 
Table 1. Differences in morbidity from chronic diseases between Greenland Eskimos and Scandinavians (from Kromann \& Green, 1980)

\begin{tabular}{lc}
\hline & Eskimos:Scandinavians \\
\hline Stroke & $2: 1$ \\
Acute myocardial infarction & $1: 10$ \\
Psoriasis & $1: 20$ \\
Diabetes & Rare \\
Bronchial asthma & $1: 25$ \\
Thyrotoxicosis & Rare \\
Multiple sclerosis & 0 \\
Epilepsy & $2: 1$ \\
Polyarthritis & Low \\
\hline \hline
\end{tabular}

Table 2. Dietary fats in Eskimo and Danish diets (daily energy intake of approximately $12.5 \mathrm{MJ}(3000 \mathrm{kcal}))$ (from Dyerberg, 1986)

\begin{tabular}{lcc}
\hline \hline & Eskimos & Danes \\
\hline Percentage of total energy from fat & 39 & 42 \\
Percentage of total fatty acids as: & & \\
Saturated (S) & 23 & 53 \\
Mono-unsaturated & 58 & 34 \\
Polyunsaturated (P) & 19 & 13 \\
P:S ratio & $0 \cdot 84$ & $0 \cdot 24$ \\
Daily intake (g) & & \\
$n$-3 PUFA & 14 & 3 \\
$n$-6 PUFA & 5 & 10 \\
Cholesterol & $0 \cdot 70$ & 0.42 \\
\hline \hline
\end{tabular}

PUFA, polyunsaturated fatty acids.

produce changes in the balance of short-lived hormone-type compounds called prostaglandins and leukotrienes. Changes produced by certain drugs in the balances of these hormones have been shown to result in remarkable effects in the treatment of two main classes of diseases, namely those affecting blood vessels and those affecting inflammatory diseases.

These ideas have led to a wealth of animal and clinical experiments testing the effects of fish oil in the treatment of a wide variety of diseases within these two main categories. It is our assessment that in the past few years more than 100 million dollars have been spent by research workers looking into this matter in thirty different countries in nearly every part of the world. Keeping up to date on these developments has been a major task during the past few years, with several hundred papers being written on this subject each year.

\section{CURRENT SITUATION}

The beneficial role of fish oil in the human diet can be divided into two main areas: (1) to sustain normal healthy life, (2) to correct certain diseases. The sustenance of normally 
healthy life can be subdivided further into two main groups to which research attention has been paid: (a) development of the fetus and young child, (b) dietary requirements of the normal adult. Similarly the main function of correcting certain diseases can be subdivided into two groups, mainly: (i) treatment of blood vessel diseases, (ii) treatment of inflammatory diseases.

\section{NORMAL HEALTHY LIFE}

Research results show that the fetus and young child might have a requirement for DHA, particularly for normal brain and nervous tissue development. Animal experiments have shown that the brain and the nervous tissue have extremely high concentrations of DHA and that maintaining rats on diets deficient in $n-3$ fatty acids over several generations results in only a modest decrease in DHA in the brain and nervous tissue. This might suggest that these organs are retaining the DHA for a particular purpose, probably because it is essential to their function (Crawford, 1987). Animal experiments have suggested that a deficiency of $n-3$ fatty acids decreases the animal's ability to learn and its ability to see properly (Neuringer et al. 1986).

Limited observations have shown that there is a dramatic increase in DHA in the human brain during the last trimester of fetus development, with the DHA level doubling during this period (Martinez et al. 1974). In addition, analysis of the fatty acid composition of human milk from Canadian Eskimos eating a traditional diet has shown an $n-3: n-6$ fatty acids ratio of 1:4. Milk taken from women in Vancouver showed a balance of 1:13 and milk from women in the USA showed an even more extreme ratio (Innis, 1989).

The NATO conference considering this subject felt that properly constituted milk fat in infant formulas should have an $n-3: n-6$ fatty acid ratio of about $1: 4$. It is interesting to note that the Canadian Department of Health and Welfare is currently considering introducing statutory values for $n-3: n-6$ fatty acids in Canadian infant formulas, following a survey in which it was discovered that current commercial products vary from 1:6.4 to 1:108.

With regard to $n-3$ fatty acid requirements for normal adults, the NATO conference received a paper from a medical worker in Norway who was treating a number of patients who had suffered brain damage and, therefore, had to be fed entirely by means of a gastric tube over many years. He discovered that diets deficient in $n-3$ fatty acids, particularly EPA and DHA, resulted in scaliness and lesions of the skin of the patients, which were cured when these fatty acids were added to the diet (Bjerve, 1989). This led him to estimate the percentage of the energy in his patients' diets which were necessary as EPA or DHA to prevent these skin problems. He concluded that $5.4 \%$ of the energy of the diet had to be in the form of PUFA and $0.2 \%$ of the energy had to be specifically EPA and DHA.

Epidemiological experiments presented at the NATO meeting, primarily based on a 30-year Dutch study (Kromhout, 1989), supported the view that even a low level of EPA and DHA in the diet results in a significant decrease in the incidence of coronary heart disease. Therefore, these fatty acids seem essential for health and well-being. Using the findings provided by the Norwegian study and the Dutch epidemiological study one can calculate that an average person living in the USA should consume about $1 \mathrm{~g}$ $\mathrm{EPA}+\mathrm{DHA} / \mathrm{d}$ in order to meet the appropriate balance of fats in his diet. 
Table 3. Effects of dietary fish oil supplements on blood vessel diseases in man

\begin{tabular}{|c|c|}
\hline $\begin{array}{l}\text { Direction } \\
\text { of change }\end{array}$ & \\
\hline$\downarrow$ & Blood fats $(3 \mathrm{~g} \mathrm{EPA}+\mathrm{DHA} / \mathrm{d})$ \\
\hline- & Total cholesterol (4 g EPA+DHA/d) \\
\hline$\uparrow ?$ & LDL-cholesterol \\
\hline$?$ & Atherosclerosis \\
\hline$\downarrow$ & Blood pressure ( $4.6 \mathrm{~g} \mathrm{EPA}+\mathrm{DHA} / \mathrm{d}$ decrease $>2$ units) \\
\hline$\downarrow$ & Platelet aggregation $(1.8-2.7 \mathrm{~g}$ EPA $+\mathrm{DHA} / \mathrm{d})$ \\
\hline$\uparrow$ & Bleeding time $(1 \cdot 8-2.7 \mathrm{~g} \mathrm{EPA}+\mathrm{DHA} / \mathrm{d})$ \\
\hline$\downarrow$ & Blood viscosity $(2-3$ g EPA +DHA/d) \\
\hline$\downarrow$ & Cardiac arrythmias (animal models) \\
\hline
\end{tabular}

EPA, eicosapentaenoic acid; DHA, docosahexaenoic acid; LDL, low-density lipoprotein; $\uparrow$, increase in measurement unit compared with placebo; $\downarrow$, decrease; -, no effect; ?, uncertain effect.

These values would need to be changed depending on the dietary pattern of the population under study. There is no such thing as an average adult. However, the value of $1 \mathrm{~g} \mathrm{EPA}+\mathrm{DHA} / \mathrm{d}$ is probably a reasonable approximation.

\section{BLOOD VESSEL DISEASES}

During coronary heart disease blood fat and total cholesterol concentrations can increase. An increase in low-density-lipoprotein (LDL)-cholesterol is suggestive of possible development of atherosclerosis. During the development of atherosclerosis, blood pressure and blood viscosity increase. The acute phase of heart disease involves platelet aggregation, ischaemia and arrhythmia.

Table 3 summarizes the many studies of the effect of dietary fish oil on blood vessel diseases. In particular, blood fats are reduced by feeding $3 \mathrm{~g}$ EPA+DHA/d. In many groups the consumption of fish oil appears to have little or no effect on total cholesterol. In some groups, but not all, LDL-cholesterol increases, which is normally regarded as an indicator of coronary heart disease. However, physicians do not regard the increase caused by fish oil as detrimental in these circumstances, but neither do they regard it as advantageous. Thus, the role of fish oil in changing cholesterol levels appears to be neutral.

Some evidence recently available indicates that fish oil may delay the onset of atherosclerosis (Leaf \& Weber, 1988). Normally about $30 \%$ of patients undergoing coronary angioplasty, an internal mechanical technique for removing atherosclerotic blockages in coronary arteries, suffer early restenosis about 9 months after surgery. This is a rapid development of atherosclerosis and provides a model for studying the preventative effect of fish oil or any other drugs. Dehmer et al. (1988) conducted a randomized unblinded study comparing a conventional antiplatelet regimen $(325 \mathrm{mg}$ aspirin and $225 \mathrm{mg}$ dipyridamole/d; control group) with a similar regimen supplemented with $3.2 \mathrm{~g} \mathrm{EPA} / \mathrm{d}$ (treatment group). In eighty-two male patients, 103 coronary lesions were dilated. The incidence of restenosis per patient 6 months after the angioplasty was significantly lower in the treatment group (19\%) compared with $46 \%$ in the control 
group. Further centres within the USA are repeating this work in order to increase sample size.

A number of experiments suggest that dietary fish oil decreases blood pressure, decreases platelet aggregation, increases bleeding time, and decreases blood viscosity (Table 3). Animal model experiments suggest that when blood flow is restricted to the cardiac muscle, dietary fish oil decreases the incidence of cardiac arrythmia in rats compared with control animals receiving high levels of saturated fat.

In summary, giving 2-3 g EPA +DHA/d can result in positive effects on many of these measured variables in man.

\section{INFLAMMATORY DISEASES}

With regard to inflammatory diseases, the three major diseases studied so far are: rheumatoid arthritis, psoriasis and asthma.

Comprehensive double-blind studies conducted with patients suffering from rheumatoid arthritis have shown that consumption of fish oil results in improvement in twenty-one of forty-five different measurements made (Kremer et al. 1988). The level of EPA and DHA required for these improvements is relatively high at $5.5 \mathrm{~g} / \mathrm{d}$. Nevertheless physicians are interested in using fish oil, possibly together with anti-inflammatory drugs, to reduce the pain and inconvenience caused by rheumatoid arthritis.

With regard to psoriasis (red scaly patchiness of the skin), a number of centres throughout the world have shown positive improvements in patients suffering from psoriasis by consumption of fish oil (e.g. Kragballe \& Fogh, 1989). Many drug treatments for this disorder appear to be unsatisfactory, with the patient suffering recurring psoriasis after a few weeks even though taking drugs. Some physicians report that fish oil has much more long-lasting effects.

A number of clinical trials have been done with patients suffering from asthma in the hope that fish oil can alleviate this unfortunate condition. The results to date suggest that fish oil does not improve the situation (Kirsch et al. 1988).

\section{OVERVIEW ON NUTRITIONAL REQUIREMENTS}

From the evidence available it does seem that EPA and DHA have a role to play in the dietary requirements of humans, with intakes of about $1 \mathrm{~g} / \mathrm{d}$ being sufficient.

Patients suffering from a number of blood vessel disorders and inflammatory diseases can positively benefit from including fish oil in their diet, with effects being noted when the dietary intake of EPA+DHA is $3 \mathrm{~g} / \mathrm{d}$ or greater. Other diseases have yet to be explored to see whether there would be benefit from dietary administration of fish oil.

\section{THE FOOD USES OF FISH OILS}

The fish oil producers of the world who currently sell $95 \%$ of their product to the fat-hardening industry have been collaborating, through the International Association of Fish Meal Manufacturers (IAFMM), to develop a number of non-fish food products which contain refined and deodorized fish oil rich in $n-3$ long-chain PUFA and which do not taste fishy. At first there were considerable doubts that it would be possible to introduce fish oils into food products without making them taste fishy. So, in 1985, the 
IAFMM decided to fund and oversee an exploratory research project. The aims of the project were: (1) to investigate refining and deodorizing technology so as to obtain fish oil with a bland flavour and an unchanged level of $n-3$ long-chain PUFA, (2) to try to stabilize the flavour of the oil, and (3) to incorporate the oil into food recipes to replace part of the customary oil or fat in the product, and taste the results.

The Leatherhead Food Research Association (LFRA), UK, was asked and agreed to carry out the work, and four representative fish oils were obtained from members of the IAFMM, ranging from South America to Europe. These fish oils vary according to species, geographical location and season in their fatty acid composition; some contain more PUFA than others and are consequently more liable to develop fishy fiavours.

It was soon clear that it was possible to refine the oil so that a bland flavour was obtained and the content of $n-3$ long-chain PUFA was not affected. It was also clear that if the oil was protected by being stored under good conditions the acceptable flavour could be retained. The project, therefore, went on to the third stage.

It was decided to try the oils in a range of foods, some of which would be strongly flavoured and therefore any flavour from the fish oil could be masked, and some of which would be sensitive to off-flavours. The foods were in six categories which are shown in Table 4 , together with the comments agreed on when they were tasted blind against a control of the same food without fish oil.

The results were very satisfactory. Margarine was not made at this stage because, due to the process equipment involved, more oil would have been necessary than was available. The reason for the production failure of the mayonnaise was not clear and it was felt that, considering the other results, the coleslaw should have been better. The IAFMM were thus, in April 1986, encouraged to continue the development work.

It was realized that the fish oil content of the foods must enable people to obtain the 1-3 g n-3 long-chain PUFA/d deemed to be desirable. The foods in the first trial had varied in their fish oil content from about $1 \%$ in the yoghurt to $100 \%$ in the canned fish. It was therefore necessary to find out how much fish oil could be incorporated. Some foods, for example margarine, have a higher oil content than others, while foods such as the meats are eaten in larger quantities. These types of food were therefore used in the next development phase. They comprised French dressing, salad cream, frankfurters, salami and margarine. The first four of these were again prepared by LFRA while, for the margarine, Grindsted Products A/S in Denmark were glad to join the work. LFRA also tackled the problem of the mayonnaise. The members of the IAFMM had elected to refine the oils in their own countries; five oils were received from which three were chosen for the trials.

LFRA staff made products and, on the basis of informal tasting, decided on the maximum level of fish oil which could be incorporated. The foods were then prepared again with the maximum concentration and at two lower levels, and were tasted by the LFRA formal tasting panel. The French dressing and salad cream were assessed $1 \mathrm{~d}$ after preparation, and salami and frankfurters after 9 and $21 \mathrm{~d}$ respectively. Each panellist received four test samples plus an unidentified control. In addition each panellist was asked to taste an identified control, to provide a reference point, before tasting the other samples. Each panellist therefore tasted six samples. Panellists were not informed that the products contained fish oil. The information collected was analysed statistically.

The trial was successful in that in all cases it proved possible to produce foods containing fish oil with acceptable flavours, and to indicate a maximum level for the use 
Table 4. Flavour assessment of food containing refined fish oils

\begin{tabular}{|c|c|c|c|c|c|}
\hline Food type & Food made & $\begin{array}{c}\text { Fat } \\
\text { content } \\
(\mathrm{g} / \mathrm{kg})\end{array}$ & $\begin{array}{c}\text { Fish oil } \\
\text { content } \\
\text { (\% of food) }\end{array}$ & $\begin{array}{c}\text { Main } \\
\text { ingredients }\end{array}$ & $\begin{array}{c}\text { Flavour } \\
\text { assessment }\end{array}$ \\
\hline \multirow[t]{3}{*}{$\begin{array}{l}\text { Spreads and } \\
\text { pastes }\end{array}$} & Fish spread & 250 & 11 & $\begin{array}{l}\text { Fish, meat, } \\
\text { oil, water, } \\
\text { starch }\end{array}$ & Acceptable \\
\hline & Cheese spread & 220 & $3 \cdot 3$ & $\begin{array}{l}\text { Milk products, } \\
\text { cheese, water }\end{array}$ & Good \\
\hline & Peanut butter & 550 & 5 & $\begin{array}{l}\text { Peanuts, oil, } \\
\text { salt }\end{array}$ & Acceptable \\
\hline Margarine & Margarine & 800 & $10 / 20$ & $\begin{array}{l}\text { Oil, water, } \\
\text { salt }\end{array}$ & Acceptable \\
\hline \multirow[t]{3}{*}{$\begin{array}{l}\text { Salads and } \\
\text { salad dressings }\end{array}$} & Salad cream & 250 & $2 \cdot 5-7 \cdot 5$ & $\begin{array}{l}\text { Vinegar, egg, } \\
\text { oil, water }\end{array}$ & Acceptable \\
\hline & Mayonnaise & 750 & & Oil, egg & \\
\hline & Coleslaw & 50 & 3 & $\begin{array}{l}\text { Vegetables, } \\
\text { French } \\
\text { dressing }\end{array}$ & Poor \\
\hline $\begin{array}{l}\text { Dairy } \\
\text { products }\end{array}$ & Yoghurt & 40 & $0 \cdot 3-1 \cdot 5$ & $\begin{array}{l}\text { Water, fat, } \\
\text { protein, sugar }\end{array}$ & Poor \\
\hline \multirow[t]{2}{*}{$\begin{array}{l}\text { Oils and oil } \\
\text { blends }\end{array}$} & French dressing & 520 & 31 & $\begin{array}{l}\text { Vinegar, oil, } \\
\text { water }\end{array}$ & Good \\
\hline & Canned fish oil & 1000 & 100 & Oil & Good \\
\hline \multirow{2}{*}{$\begin{array}{l}\text { Sausages, } \\
\text { smoked and } \\
\text { spiced foods }\end{array}$} & Salami & 230 & 2 & $\begin{array}{l}\text { Beef, pork } \\
\text { meats, water }\end{array}$ & Good \\
\hline & Pork sausage & 300 & 3 & $\begin{array}{l}\text { Pork meat } \\
\text { and fat, water, } \\
\text { fibre }\end{array}$ & Good \\
\hline
\end{tabular}

of the sample of a particular oil for a food. As was stated earlier, because of the different compositions of the oils, the maximum levels usable were also different.

The results of the LFRA trial are given in Table 5 together with weights of the foods per serving or meal and the consequent intake of $n-3$ long-chain PUFA, based on a rough mean of $20 \%$ of these fatty acids in the fish oil. It is clear that the target intake of as much as $3 \mathrm{~g} n$-3 long-chain PUFA/d can be achieved.

The mayonnaise was successful in that a good product was made, but the terms of the project did not include its formal tasting. However, informal tasting indicated the possibility of a satisfactory product incorporating over $30 \%$ fish oil which, in a $20 \mathrm{~g}$ serving, is equivalent to at least $1.2 \mathrm{~g} n-3$ long-chain PUFA.

For the margarine, two of the refined fish oils were used, each blended at two levels with the vegetable oils, and these were compared with a $100 \%$ vegetable oil control. The effects of three styles of packaging were tried. The products were tasted by a Grindsted Products taste panel and by members of the IAFMM from different parts of the world. 
Table 5. Estimated content of eicosapentaenoic acid (EPA) and docosahexaenoic acid (DHA) per serving in food products made with fish oil

\begin{tabular}{lcccc}
\hline Food & $\begin{array}{c}\text { Fish oil }(\% \text { of } \\
\text { total oil) }\end{array}$ & $\begin{array}{c}\text { Serving } \\
(\mathrm{g})\end{array}$ & $\begin{array}{c}\text { Fish oil } \\
\text { per serving } \\
(\mathrm{g})\end{array}$ & $\begin{array}{c}\text { EPA+DHA* } \\
\text { per serving } \\
(\mathrm{g})\end{array}$ \\
\hline Margarine & 10 & $50 / \mathrm{d}$ & $5 \cdot 0$ & $1 \cdot 0$ \\
Salad cream & 10 & $20 /$ serving & $2 \cdot 0$ & $0 \cdot 4$ \\
French dressing & 10 & $20 /$ serving & $2 \cdot 0$ & $0 \cdot 4$ \\
Frankfurters & $16 \cdot 5$ & $100 /$ meal & 16.5 & $3 \cdot 3$ \\
Salami & 10 & $50 /$ meal & $5 \cdot 0$ & $1 \cdot 0$ \\
\hline \hline
\end{tabular}

${ }^{*}$ Based on $20 \%$ EPA +DHA in fish oil.

The results were promising. They showed that it is possible, even with the logistical problems of transferring refined oils sensitive to oxidation over long distances and with no special plant precautions, to make margarines containing $10-20 \%$ fish oil of good initial edibility and with a shelf life of a few weeks.

We have learned from these trials that: (1) food products can be made with acceptable taste incorporating enough unhydrogenated fish oil to supply up to $3 \mathrm{~g} n-3$ long-chain PUFA/d; (2) the flavour stability of these products must be improved; and (3) research is needed on the mechanisms of off-flavour development both in the oils themselves and in the total food product. These subjects are currently being addressed by the IAFMM as part of its continuing involvement in research on the use of fish oil in foods.

\section{REFERENCES}

Bjerve, K. S. (1989). Omega 3 and omega 6 fatty acids in serum lipids and their relationship to human disease. In Dietary $\omega 3$ and $\omega 6$ Fatty Acids. Biological Effects and Nutritional Essentiality, pp. 241-251 [C. Galli and A. P. Simopoulos, editors]. New York: Plenum Publishing Corp.

Crawford, M. A. (1987). The requirements of long-chain $n-6$ and $n-3$ fatty acids for the brain. In Proceedings of the AOCS Short Course on Polyunsaturated Fatty Acids and Eicosanoids, pp. 270-295 [W. E. M. Lands, editor]. Illinois: American Oil Chemists' Society.

Dehmer, G. J., Popma, J. J., van den Berg, E. K., Eichorn, E. J., Prewitt, J. B., Campbell, W. B., Jennings, L., Willerson, J. T. \& Schmitz, J. M. (1988). Reduction in the rate of early restenosis after coronary angioplasty by a diet supplemented with $n-3$ fatty acids. New England Journal of Medicine 319, 733-740.

Dyerberg, J. (1982). Observations on populations in Greenland and Denmark. In Nutritional Evaluation of Long-Chain Fatty Acids in Fish Oil, pp. 245-262 [S. M. Barlow and M. E. Stansby, editors]. London: Academic Press.

Dyerberg, J. (1986). The Eskimo experience. $n-3$ News 1(1), $1-4$.

Galli, C. \& Simopoulos, A. P. (editors) (1989). Dietary $\omega 3$ and $\omega 6$ Fatty Acids. Biological Effects and Nutritional Essentiality. New York: Plenum Publishing Corp.

Innis, S. M. (1989). Sources of $\omega 3$ fatty acids in Arctic diets and their effects on red cell and breast milk fatty acids in Canadian Inuit. In Dietary $\omega 3$ and $\omega 6$ Fatty Acids. Biological Effects and Nutritional Essentiality, pp. 135-146 [C. Galli and A. P. Simopoulos, editors]. New York: Plenum Publishing Corp.

Kirsch, C. M., Payan, D. G., Wong, M. Y. S., Dohlman, J. G., Blake, V. A., Petri, M. A., Offenberger, J., Goetzl, E. J. \& Gold, W. M. (1988). Effect of eicosapentaenoic acid in asthma. Clinical Allergy 18, 177-187.

Kragballe, K. \& Fogh, K. (1989). A low-fat diet supplemented with dietary fish oil (MAX-EPA) results in improvement of psoriasis and the formation of leukotriene 35 . Acta Dermato-Venereologica (Stockholm) 69, 23-28. 
Kremer, J., Lawrence, D. \& Jubiz, W. (1988). Different doses of fish oil fatty acid supplementation in rheumatoid arthritis. A prospective double-blinded randomised study. Arthritis and Rheumatism 31, 530 (Abstr).

Kromann, N. \& Green, A. (1980). Epidemiological studies in the Upernavik district, Greenland. Acta Medica Scandinavica 208, 401-406.

Kromhout, D. (1989). Fish (oil) consumption and coronary heart disease. In Dietary $\omega 3$ and $\omega 6$ Fatty Acids. Biological Effects and Nutritional Essentiality, pp. 273-282 [C. Galli and A. P. Simopoulos, editors]. New York: Plenum Publishing Corp.

Lands, W. E. M. (1982). Biochemical observations on dietary long-chain fatty acids from fish oil and their effect on prostaglandin synthesis in animals and humans. In Nutritional Evaluation of Long-Chain Fatty Acids in Fish Oil, pp. 267-282 [S. M. Barlow and M. E. Stansby, editors]. London: Academic Press.

Leaf, A. \& Weber, P. C. (1988). Cardiovascular effects of $n-3$ fatty acids: an update. $n-3$ News 3(4), 1-7.

Martinez, M., Conde, C. \& Ballabriga, A. (1974). Some chemical aspects of human brain development. II. Phosphoglyceride fatty acids. Pediatric Research 8, 93.

Neuringer, M., Connor, W. E., Lin, D. S., Barstad, L. \& Luck, S. (1986). Biochemical and functional effects of prenatal and postnatal $\omega 3$ fatty acid deficiency on retina and brain in Rhesus monkeys. Proceedings of the National Academy of Sciences, USA 83, 4021-4025.

Nordoy, A. \& Dyerberg, J. (1990). Acta Medica Scandinavica (In the Press).

Stansby, M. E. (1982). A clinical study on the role of fish oil in alleviating human heart disease. In Nutritional Evaluation of Long-Chain Fatty Acids in Fish Oil, pp. 263-266 [S. M. Barlow and M. E. Stansby, editors]. London: Academic Press. 